\title{
De NOW en bedrijfseconomisch ontslag: de spagaat van een werkgever die loonkostensubsidie aanvraagt, maar tegelijkertijd moet reorganiseren
}

\author{
mr. Juno Terpstra*
}

\section{Inleiding}

Sinds 6 april 2020 kunnen werkgevers een loonkostensubsidie aanvragen onder de Tijdelijke noodmaatregel overbrugging voor behoud van werkgelegenheid ('NOW'). ${ }^{1}$ De NOW is onderdeel van een breder pakket aan steunmaatregelen dat de regering heeft geintroduceerd om de economische gevolgen van de coronapandemie en de daarmee verband houdende overheidsmaatregelen te ondervangen. Het doel van de NOW is om werkgevers tegemoet te komen in de betaling van de loonkosten om zo een periode van substantieel omzetverlies als gevolg van de coronacrisis te kunnen overbruggen. ${ }^{2}$ De NOW stelt werkgevers door een loonkostensubsidie in staat hun werknemers in deze economisch turbulente tijden door te blijven betalen en zo veel mogelijk in dienst te houden. De loonkostensubsidieregeling moet op die manier grootschalige ontslagen en werkloosheid voorkomen. ${ }^{3}$ Deze doelstelling vertaalt zich in twee kernverplichtingen voor de werkgever die een beroep wil doen op de NOW: (i) de werkgever is verplicht de loonsom zo veel mogelijk gelijk te houden, en (ii) de werkgever mag gedurende de loonkostensubsidieperiode geen ontslagaanvragen om bedrijfseconomische redenen indienen bij het UWV. Deze verplichtingen zijn een uitwerking van de verantwoordelijkheid die

Juno Terpstra is werkzaam als advocaat bij Stibbe.

1. De Tijdelijke noodmaatregel overbrugging voor behoud van werkgelegenheid (Stcrt. 2020, 19874) ('NOW-1'). De NOW-1 is na de inwerkingtreding een aantal keer gewijzigd, namelijk op 4 april 2020 (Stcrt. 2020, 20561), op 5 mei 2020 (Stcrt. 2020, 25372) en op 28 mei 2020 (Stcrt. 2020, 29256, met een rectificatie in Stcrt. 2020, 29256n1), gezamenlijk de Eerste tijdelijke noodmaatregel overbrugging voor behoud van werkgelegenheid. Op 25 juni 2020 verscheen de Tweede tijdelijke noodmaatregel overbrugging voor behoud van werkgelegenheid in de Staatscourant (Stcrt. 2020, 34308) ('NOW-2'). Per 1 oktober 2020 is een aantal wijzigingen aangebracht in de NOW-1 en de NOW-2 (Stcrt. 2020, 50202). De NOW-1 en de NOW-2 vormen samen de NOW.

2. Zie art. 3 NOW-1 / NOW-2

3. Zie de Kamerbrief Tijdelijke noodmaatregel overbrugging voor behoud van werkgelegenheid (Kamerstukken // 2019/20, 35420, nr. 8) en de toelichting bij de NOW-1 (Stcrt. 2020, 19874, p. 9). de NOW van werkgevers (en de vakbonden) vraagt om tijdens de coronacrisis in te zetten op een zo groot mogelijk behoud van werkgelegenheid in Nederland. ${ }^{4}$ Een werkgever kan onder de NOW dus een beroep doen op overheidssteun, maar daartegenover staat een beperking van de ruimte van de werkgever om bedrijfseconomische ontslagen door te voeren.

Deze bijdrage geeft een overzicht van de kernverplichtingen op het gebied van bedrijfseconomisch ontslag waaraan een werkgever zich bij een beroep op de NOW moet houden en de consequenties die de NOW verbindt aan het niet naleven daarvan. Ik bespreek zowel de eerste tranche van de NOW die geldt voor de subsidieperiode 1 maart 2020 tot en met 31 mei 2020 ('NOW-1') als de tweede tranche van de NOW die geldt voor subsidieperiode 1 juni 2020 tot en met 30 september 2020 ('NOW-2'). ${ }^{5}$ Ik sta hierna eerst stil bij de plaats van de verplichtingen in de NOW, de bevoegdheden die het UWV heeft indien deze niet worden nageleefd en de rechtsbescherming die de werkgever geniet. Daarna ga ik achtereenvolgens in op de verplichting om de loonsom zo veel mogelijk gelijk te houden en de verplichting om geen bedrijfseconomisch ontslag aan te vragen. Hierbij besteed ik andacht aan de belangriikste afwegingen die een werkgever in dit verband moet maken. Dit is relevant omdat ondernemingen vanwege de aanhoudende coronacrisis kampen met langduriger verliezen en maatregelen moeten nemen om op te lange termijn te kunnen blijven bestaan. Het is in deze tijden goed denkbaar dat een werkgever een beroep doet op de NOW om het hoofd boven water te houden, maar zich desondanks genoodzaakt ziet om te besparen op personeelskosten. Daarnaast kan een werkgever door bepaald

5. Inmiddels is bekend dat er een derde pakket aan financiële steunmaatregelen komt dat onder meer bestaat uit een verlenging van de NOW tot 1 juli 2021 ('NOW-3'). Op 30 september 2020 heeft de regering de Tweede Kamer in de Kamerbrief Tijdelijke Noodmaatregel Overbrugging voor Werkbehoud 3, vaststellingsproces NOW 1 en wijzigingsregeling NOW 1 en 2 geïnformeerd over de voorwaarden van de NOW-3 (Kamerstukken I/ 2019/20, 35420, nr. 142). De tekst van de regeling van de NOW-3 was op het moment van schrijven van deze bijdrage nog niet bekend en blijft om die reden verder buiten beschouwing. De regeling zal naar verwachting medio oktober 2020 in de Staatscourant worden gepubliceerd. 
(onbewust) gedrag uiteindelijk recht hebben op een ander subsidiebedrag dan initieel geschat. Uit mijn bijdrage zal blijken dat de NOW het bemoeilijkt om beide routes tegelijkertijd te bewandelen, omdat het doorvoeren van bedrijfseconomische ontslagen ertoe kan leiden dat de subsidie lager of zelfs op nihil wordt vastgesteld. Dit kan een gehele of gedeeltelijke terugvordering van het ontvangen voorschot als gevolg hebben. De werkgever kan in dat geval bij het UWV in bezwaar gaan tegen de subsidievaststelling, maar het UWV is gebonden aan de NOW, die weinig beleidsvrijheid geeft. De bestuursrechtelijke route zou in bepaalde situaties desalniettemin uitkomst kunnen bieden, maar dan via de weg van de exceptieve toetsing door de rechter. Dit is echter een hoge drempel waar de werkgever overheen moet. Ik sluit af met de belangrijkste knelpunten die ik zie tussen de verplichtingen in de huidige NOW en de economische realiteit waar werkgevers mee te maken hebben, waarbij ik tevens vooruitkijk naar de aangekondigde verlenging van de NOW.

\section{Plaats van de verplichtingen in de NOW, bevoegdheden} van het UWV en
rechtsbescherming

\subsection{Plaats van de verplichtingen in de NOW en} bevoegdheden van het UWV

De verplichtingen die zien op bedrijfseconomisch ontslag zijn neergelegd in artikel 13 lid 1 sub a en sub b NOW-1 en artikel 15 sub a en sub b NOW-2. Deze bepalingen bevatten een opsomming van een aantal specifieke verplichtingen voor werkgevers die een beroep doen op de loonkostensubsidie, waaronder de verplichting om de subsidie enkel te gebruiken voor de betaling van de loonkosten (art. 13 lid 1 sub c NOW-1 en art. 15 sub d NOW-2). Bijkomende controleverplichtingen, zoals de verplichting om een controleerbare administratie te voeren en deze vijf jaar te bewaren (art. 13 lid 1 sub e NOW-1 en art. 15 sub f NOW-2), moeten het UWV in staat stellen om achteraf na te gaan of aan alle voorwaarden is voldaan en de loonkostensubsidie terecht is verstrekt. ${ }^{6}$

De NOW is een subsidieregeling die twee fases kent. Eerst besluit het UWV over de subsidieverlening en betaalt op basis daarvan een voorschot uit aan de werkgever. ${ }^{7}$ De werkgever dient na afloop van de subsidieperiode een aanvraag in bij het UWV voor de subsidievaststelling. Het UWV besluit binnen 52 weken op deze aanvraag en stelt het subsidiebedrag definitief vast. ${ }^{8} \mathrm{Op}$ de besluitvorming van het UWV zijn de algemene regels uit de Algemene wet bestuursrecht ('Awb')

6. Toelichting bij de NOW-1 (Stcrt. 2020, 19874, p. 16).

Art. 9 en 11 NOW-1 en art. 11 en 13 NOW-2.

Art. 14 NOW-1 en art. 18 NOW-2. Zie ook art. 4:42 en 4:44 Awb. van toepassing. Dit betekent onder meer dat het UWV bevoegd is om de subsidie na afloop van de subsidieperiode lager vast te stellen dan de verleende subsidie indien de werkgever niet heeft voldaan aan de aan de subsidie verbonden verplichtingen (art. 4:46 Awb). Onder de NOW is het UWV voorts bevoegd om (i) de betaling van het voorschot op te schorten indien er een ernstig vermoeden bestaat dat de werkgever niet aan zijn verplichtingen voldoet (art. $12 \mathrm{NOW}-1$ en art. 14 NOW-2), en (ii) het verstrekte voorschot geheel of gedeeltelijk terug te vorderen indien dit ten onrechte of voor een te hoog bedrag is verstrekt of indien niet aan de hierboven omgeschreven verplichtingen is voldaan (art. 15 NOW-1 en art. 19 NOW-2). Het UWV heeft de bevoegdheid om bij de subsidievaststelling het subsidiebedrag te korten of zelfs op nihil te stellen, waarbij de NOW het UWV weinig beleidsvrijheid geeft voor wat betreft de wijze waarop het met deze bevoegdheid omgaat. Het niet naleven van de verplichtingen uit de NOW kan dus grote gevolgen hebben voor de subsidie waar de werkgever recht op heeft.

\subsection{Rechtsbescherming}

Het besluit tot de subsidieverlening en het besluit tot de subsidievaststelling zijn allebei appellabele besluiten waartegen de bestuursrechtelijke rechtsgang open staat. De werkgever kan binnen zes weken tegen het besluit bezwaar aantekenen bij het UWV (art. 6:7 Awb). ${ }^{9}$ De werkgever kan vervolgens binnen zes weken na het besluit van het UWV op het bezwaar in beroep bij de bestuursrechter (art. 6:9 Awb). Hoger beroep kan worden ingesteld bij de Centrale Raad van Beroep. ${ }^{10}$

Als bestuursorgaan is het UWV bij de beoordeling van het bezwaar gebonden aan de NOW. De NOW kent specifieke regels met betrekking tot de berekening van het subsidiebedrag en de gevolgen van bepaalde feiten, zoals een loonsomdaling, op de hoogte van dit bedrag. Slechts in een beperkt aantal gevallen voorziet de NOW in een uitzondering. Illustratief is het feit dat het UWV alleen kan afwijken van de referentiemaand voor de loonsom indien er geen loonsomgegevens beschikbaar zijn over deze maand, niet als deze om bepaalde redenen niet representatief zijn. ${ }^{11}$ De regering heeft er bovendien voor gekozen om geen hardheidsclausule op te nemen in de NOW, op grond waarvan het UWV in bijzondere omstandigheden kan afwijken van een of

9. De Minister van Sociale Zaken en Werkgelegenheid heeft alle taken omtrent de uitvoering van de NOW gedelegeerd aan het UWV, zo ook de beslissing en behandeling van bezwaarschriften tegen besluiten die zijn genomen op grond van de NOW (art. 17 NOW-1 en art. 21 NOW-2).

10. Bij de invoering van de NOW-1 is niet eenduidig vastgesteld of de Centrale Raad van Beroep of de Afdeling Bestuursrechtspraak van de Raad van State bevoegd was om in hoger beroep te oordelen in bestuursrechtelijke procedures over de NOW. In de eerste uitspraken over de NOW hebben rechters overwogen dat de Centrale Raad van Beroep bevoegd is (zie Rb. Noord-Nederland 25 augustus 2020, ECLI:NL:RBNNE:2020:2911 en Rb. Zeeland-West-Brabant 28 juli 2020, ECLI:NL:RBZWB:2020:3479). De Centrale Raad van Beroep heeft zich nog niet uitgelaten over zijn bevoegdheid.

11. Art. 10 lid 3 NOW-1 en art. 8 lid 3 NOW-2. 
meer bepalingen daaruit. Dit past bij het karakter van de NOW van een snel toepasbare regeling, maar heeft als gevolg dat het UWV bij de uitvoering van de NOW (bijna) geen beleidsvrijheid heeft om rekening te houden met de omstandigheden in een individueel geval. Dit wordt bevestigd in de eerste NOW-uitspraken, waarin is geoordeeld dat de peildatum voor de loonkosten een 'harde datum' is waarvan niet kan worden afgeweken, waarbij van belang is dat de NOW geen hardheidsclausule kent. ${ }^{12}$

Dit neemt niet weg dat het voor een werkgever alsnog nuttig kan zijn om in bezwaar te gaan bij het UWV. In de eerste plaats leren de eerste praktijkervaringen met de NOW dat de bezwaren die door werkgevers zijn aangevoerd bij het UWV worden gemonitord door het UWV en de Minister van Sociale Zaken en Werkgelegenheid (de 'Minister'). De Minister heeft de NOW reeds enkele malen gewijzigd om sommige pijnpunten weg te nemen. ${ }^{13}$ In de tweede plaats vormt het besluit op bezwaar het benodigde toegangskaartje voor een toetsing door de bestuursrechter. Eenmaal bij de rechter heeft de werkgever meer - maar alsnog niet veel - ruimte om te pleiten voor een uitzondering in zijn individuele geval. De rechter kan in uitzonderlijke gevallen oordelen dat een bepaling uit de NOW wegens strijd met algemene rechtsbeginselen en algemene beginselen van behoorlijk bestuur buiten toepassing moet worden gelaten (exceptieve toetsing). ${ }^{14}$ Hier kom ik later op terug.

\section{Verplichting om de loonsom zo veel mogelijk gelijk te houden}

\subsection{Doelstelling en gevolgen bij niet-naleving}

De eerste kernverplichting die geldt bij een beroep op de NOW is de verplichting om de loonsom zo veel mogelijk gelijk te houden (art. 13 lid 1 sub a NOW-1 en art. 15 sub a NOW-2). Dit betreft een inspanningsverplichting voor de werkgever om zijn werknemers in dienst te houden en hun lonen te blijven doorbetalen, ook indien daartoe geen verplichting bestaat. De verplichting beoogt vooral dat de werkgever die loonkostensubsidie ontvangt tijdelijke arbeidsovereenkomsten voortzet en ook de werknemers met een flexibele arbeidsomvang, zoals oproepkrachten, doorbetaalt,

12. Rb. Noord-Nederland 25 augustus 2020, ECLI:NL:RBNNE:2020:2911 en Rb. Zeeland-West-Brabant 28 juli 2020, ECLI:NL:RBZWB: 2020:3479

13. Hierbij kan geworden gedacht aan de invoering van de concern-uitzondering (Stcrt. 2020, 25372) en de invoering van een herstelmogelijkheid voor het aanvragen van subsidie op werkmaatschappij niveau (Stcrt. 2020, 50202).

14. Zie CRvB 1 juli 2019, ECLI:NL:CRVB:2019:2016 en recent met betrekking tot de NOW Rb. Midden-Nederland 9 september 2020, ECLI:NL:RBMNE:2020:3813. zodat de werkgelegenheid zo veel mogelijk behouden blijft. ${ }^{15}$

Indien een werkgever deze verplichting niet naleeft en de loonsom tijdens de subsidieperiode is gedaald, heeft deze daling een direct effect op de hoogte van het subsidiebedrag waar de werkgever recht op heeft. Dit heeft te maken met de systematiek van de NOW en de wijze waarop de loonkostensubsidie wordt berekend. De subsidie is een percentage van de totale loonsom van de werkgever over de subsidieperiode. Dit percentage wordt gerelateerd aan het omzetverlies en loopt op tot maximaal $90 \%$ bij een omzetdaling van $100 \%$. De loonsom is daarmee een directe variabele bij de berekening van de subsidie, zodat een daling in de loonsom - oftewel een verlies aan werkgelegenheid - leidt tot een lager subsidiebedrag. ${ }^{16}$

Indien een werkgever een aanvraag voor NOW indient bij het UWV, wordt de subsidie in eerste instantie gebaseerd op de loonsom in de toepasselijke referentiemaand. Dit is in beginsel januari 2020 (NOW-1) of maart 2020 (NOW-2). Om de werkgever snel van steun te kunnen voorzien, keert het UWV een voorschot uit van $80 \%$ van het verleende subsidiebedrag. $\mathrm{Na}$ afloop van de subsidieperiode wordt de subsidie definitief vastgesteld en vindt een verrekening plaats met het betaalde voorschot. Blijkt bij de vaststelling van de subsidie dat de loonsom over de subsidieperiode is gedaald ten opzichte van de loonsom in de referentiemaand, dan wordt de subsidie lager vastgesteld. ${ }^{17}$ De werkgever die zijn loonsom niet gelijk heeft gehouden, loopt het risico op een gehele of gedeeltelijke terugvordering indien de subsidie daardoor lager uitvalt dan het voorschot dat hij heeft ontvangen. Andersom geldt dat een hogere loonsom in de subsidieperiode niet leidt tot een hogere vaststelling van de subsidie. ${ }^{18}$

\subsection{De impact van een loonsomdaling voor werkgevers met minder dan $100 \%$ omzetverlies}

Het risico op een terugvordering van de loonkostensubsidie is met name reëel voor werkgevers die minder dan $100 \%$ omzetverlies hebben. Een loonsomdaling heeft voor hen namelijk een groter effect op de hoogte van het uiteindelijke subsidiebedrag. Bij de doorberekening van een loonsomdaling in het subsidiebedrag vindt geen correctie plaats voor het omzetverlies. Dit betekent dat de subsidie met 90 cent wordt verlaagd voor elke euro waarmee de loonsom in de subsidieperiode is gedaald, ongeacht het percentage omzetverlies en dus het percentage van de loonkosten dat wordt gesubsidieerd. Werkgevers die minder dan 100\% omzetverlies hebben en bijvoorbeeld slechts $40 \%$ van de loonkosten krijgen vergoed, worden alsnog voor $90 \%$ afgerekend voor elke euro aan loonsomdaling. Deze berekeningsmethode kan

\footnotetext{
15. Toelichting bij de NOW-1 (Stcrt. 2020, 19874, p. 14).

16. Toelichting bij de NOW-1 (Stcrt. 2020, 19874, p. 10).

17. Zie voor de subsidievaststelling art. 7 NOW-1 en art. 8 NOW-2

18. Toelichting bij de NOW-1 (Stcrt. 2020, 19874, p. 15).
} 
ertoe leiden dat de werkgever onevenredig veel moet terugbetalen. Op 4 april 2020 is de NOW-1 op dit punt gewijzigd om te verduidelijken dat dit inderdaad de bedoeling is bij een loonsomdaling. ${ }^{19}$ De impact van een loonsomdaling laat zich het beste illustreren met een rekenvoorbeeld, waarbij ik bij de berekening uitga van de NOW-1:

- Werkgever 1 heeft een loonsom van $€ 150.000$ in januari 2020 en heeft een omzetverlies van 30\%. Zijn loonsom is in de subsidieperiode gelijk gebleven. Zijn subsidie onder de NOW-1 is: ${ }^{20} 0,3 \mathrm{x}$ $150.000 \times 3 \times 1,3 \times 0,9=€ 157.950$

- Werkgever 2 heeft een loonsom van $€ 200.000$ in januari 2020 met ook een omzetverlies van 30\%. Zijn loonsom is in de subsidieperiode maart - mei 2020 gedaald naar $€ 150.000$ per maand (dus gelijk aan werkgever 1). Zijn subsidie onder de NOW-1 is: ${ }^{21}$

- Subsidieverlening: $0,3 \times 200.000 \times 3 \times 1,3 \times 0,9$ $=€ 210.600$

- Correctie: $(200.000 \times 3)-(3 \times 150.000)$ x $1,3 \times$ $0,9=€ 175.500$

- Definitieve subsidie na verrekening $=€ 210.600$ $-€ 175.500=€ 35.100$

Werkgever 2 heeft uiteindelijk recht op een aanzienlijk lager subsidiebedrag dan werkgever 1 , terwijl beide werkgevers worden geconfronteerd met een omzetdaling van 30\% en ongeveer gelijke loonkosten moeten dragen. Werkgever 2 wordt 'afgerekend' omdat zijn loonsom in de subsidieperiode met $€ 50.000$ is gedaald. Het is in beginsel niet meer dan redelijk dat het subsidiebedrag van werkgever 2 lager wordt vastgesteld: achteraf had hij minder loonkosten en dus minder subsidie nodig. Het vormt bovendien een sterke prikkel voor de werkgever om zijn loonsom zo veel mogelijk gelijk te houden. Het is echter de vraag of het redelijk is dat de subsidie met $€ 175.500$ wordt verlaagd. Indien werkgever 2 tijdens de subsidieperiode een beleid heeft gevoerd van het niet verlengen van tijdelijke arbeidsovereenkomsten om bedrijfseconomische redenen, zou je de drastische verlaging van de subsidie kunnen zien als een sanctie die op zijn plaats is omdat de werkgever in strijd heeft gehandeld met de doelstelling van de NOW.

Er zijn daarentegen ook situaties te bedenken waarin een dergelijke drastische verlaging onredelijk is. Het is mogelijk dat de loonsom daalt zonder dat de werkgever daar zelf invloed op heeft, bijvoorbeeld omdat enkele werknemers hebben opgezegd of omdat werknemers met pensioen zijn gaan. Daarnaast kan een werkgever een tijdelijke arbeidsovereenkomst niet verlengen om andere redenen dan bedrijfseconomische, waarbij kan worden gedacht aan een werknemer die niet geschikt blijkt te zijn voor zijn of haar functie. In deze situaties

19. Zie Stcrt. 2020, 20561 en de Brief van de regering inzake de Tijdelijke noodmaatregel overbrugging voor behoud van werkgelegenheid (Kamerstukken I/ 2019/20, 35420, nr. 14).

20. Zie art. 7 NOW-1 en art. 10 NOW-1.

21. Art. 7 NOW-1 en art. 10 NOW-1. kan niet worden gezegd dat de werkgever direct in strijd heeft gehandeld met het doel van de NOW. Toch verbindt de NOW dezelfde consequentie aan een loonsomdaling om deze redenen. De regering heeft erkend dat de rekenmethode niet altijd de gewenste uitkomst zal hebben. Er is op dit punt echter gekozen voor eenvoud boven maatwerk, zodat de NOW geen uitzonderingen kent voor deze situaties. ${ }^{22}$

\subsection{Belangrijke afwegingen voor de werkgever}

Het is niet onwaarschijnlijk dat werkgevers die een beroep doen op de NOW tegen deze beperkingen aanlopen. Werkgevers grijpen in economisch zware tijden over het algemeen eerst naar maatregelen zoals het niet verlengen van tijdelijke arbeidsovereenkomsten of het niet meer oproepen van flexibele arbeidskrachten. Werkgevers kiezen pas voor de weg naar het UWV indien verdergaande kostenbesparingen nodig blijken. Indien een werkgever NOW aanvraagt, maar ook voorziet dat hij zal moeten snijden in de flexibele schil van zijn personeelsbestand, dan is het van belang om van tevoren rekening te houden met de gevolgen die dat kan hebben voor de hoogte van de loonkostensubsidie. De werkgever zal in kaart moeten brengen hoeveel werknemers tijdens de subsidieperiode uit dienst zullen treden en wat het effect zal zijn op zijn loonkosten. Dit geldt ook voor de werkgever die niet bewust bespaart op de loonkosten, maar al vrijwel direct na de referentiemaand een lagere loonsom had en daardoor weinig invloed heeft gehad op de loonsomdaling ten opzichte van de referentiemaand.

De werkgever die voorziet dat zijn loonsom lager zal uitvallen dan de toepasselijke referentiemaand, kan voorafgaand aan de subsidievaststelling actie ondernemen om de gevolgen tegen te gaan of in ieder geval zo veel mogelijk te dempen. Praktische middelen die de werkgever kan aangrijpen zijn onder meer het opdrijven van de loonkosten tijdens de subsidieperiode door zzp'ers tijdelijk in dienst te nemen of (statutair) bestuurders een arbeidsovereenkomst aan te bieden die voorheen op basis van een opdrachtovereenkomst werkten. Door personeel op de loonlijst te zetten dat normaal niet wordt meegenomen bij de loonsom, kan de werkgever de loonsomdaling verminderen of wellicht helemaal wegcijferen. Ook kan de werkgever een eenmalige bonus uitkeren aan werknemers, waarbij wel rekening moet worden gehouden met de beperkingen die het bonusverbod hier met zich brengt. ${ }^{23}$ De werkgever kan een eenmalige onkostenvergoeding uitbetalen voor de kosten van het inrichten van een ergonomische thuiswerkplek of andere door werknemers gemaakte kosten vergoeden. Naast het verhogen van de loonkosten zou de werkgever ook nog kunnen denken aan maatregelen om de omzet tijdens de subsidieperiode verder te drukken. Indien de gerealiseerde omzetdaling bij de subsidievaststelling hoger is dan in eerste instantie geschat, heeft de werkgever recht op een hoger percentage vergoeding van de loonkosten.

22. Toelichting bij de NOW-1 (Stcrt. 2020, 20561, p. 3).

23. Art. $6 a$ lid 1 sub d NOW-1 en art. 17 lid 1 en 3 NOW-2. 
Dit kan de gevolgen van een loonsomdaling enigszins dempen. De werkgever moet bij het nemen van dit soort maatregelen echter erop letten dat hij zich niet schuldig makkt aan misbruik: wanneer de werkgever bewust handelingen verricht om in aanmerking te komen voor een hoger subsidiebedrag, is het UWV bevoegd de subsidievaststelling in te trekken of te wijzigen. ${ }^{24}$ Het bewust drukken van de omzet, bijvoorbeeld door het later factureren van tijdens de subsidieperiode verrichte werkzaamheden, zal snel als misbruik worden gezien. Een verhoging van de loonkosten door eenmalige bonusbetalingen of uitkeringen van andere vergoedingen zal misschien minder snel als misbruik worden gezien, maar kan maatschappelijk weer gevoelig liggen aangezien de werkgever tegelijkertijd aanspraak maakt op overheidssteun.

Indien de werkgever geen rekening houdt met een lagere loonsom tijdens de subsidieperiode, dan kan hij bij de subsidievaststelling voor onaangename verrassingen komen te staan en eventueel worden geconfronteerd met een terugvordering. Het voorschot van $80 \%$ van de subsidieverlening geeft enige ruimte voor correcties, maar die $20 \%$ zal niet altijd voldoende zijn om de impact van een loonsomdaling op te vangen. Voorziet de werkgever een loonsomdaling, dan doet de werkgever er dus goed aan om (indien mogelijk) een deel van het voorschot opzij te zetten voor de verrekening bij de subsidievaststelling. De werkgever kan ook in bezwaar gaan tegen de lagere subsidievaststelling. Hierboven heb ik al aangestipt dat het UWV bij de beoordeling van het bezwaar weinig tot geen beleidsvrijheid heeft. In beroep is daarentegen meer ruimte voor de omstandigheden van een individuele werkgever: de werkgever kan verzoeken om exceptieve toetsing en betogen dat de correctie voor de loonsomdaling in zijn situatie onevenredig uitpakt. De werkgever moet dit al in de bezwaarprocedure bij het UWV naar voren brengen. Dit kan met name een interessante route zijn voor de werkgever van wie de loonsom buiten zijn toedoen om is gedaald maar die toch wordt geconfronteerd met een drastische subsidieverlaging. Indien de rechter van oordeel is dat de NOW op dit punt in strijd is met het evenredigheidsbeginsel, kan hij de bepaling om die reden buiten toepassing laten. De lat bij deze exceptieve toets ligt echter hoog. De rechter toetst marginaal en zal meewegen dat de regering er bewust voor heeft gekozen om voor dit soort situaties geen uitzondering te maken. $\mathrm{Nu}$ de regering de negatieve gevolgen heeft meegewogen maar deze klaarblijkelijk niet doorslaggevend heeft geacht, zal de rechter deze afweging niet snel doorkruisen. Tot slot is ook hier van belang dat de NOW geen hardheidsclausule bevat. In een recente uitspraak hebben deze omstandigheden ertoe geleid dat de rechter geen reden zag om de voorgeschreven peildatum voor de loonsom bij de subsidieverlening buiten toepassing te laten. ${ }^{25}$

24. Art. 16 NOW-1 en art. 20 NOW-2

25. Rb. Midden-Nederland 9 september 2020, ECLI:NL:RBMNE:2020:3813.

\section{Bedrijfseconomisch ontslag via het UWV}

\subsection{Verplichting om geen bedrijfseconomisch ontslag aan te vragen}

Een tweede belangrijke voorwaarde in de NOW is de verplichting om geen ontslagaanvraag in te dienen om bedrijfseconomische redenen (art. 13 lid 1 sub $b$ NOW-1 en art. 15 sub b NOW-2). Van de werkgever die een tegemoetkoming in de loonkosten ontvangt, wordt verwacht dat hij zich committeert geen ontslag aan te vragen bij het $\mathrm{UWV} .^{26}$ De regering makte gelijk bij de aankondiging van de NOW op 17 maart 2020 bekend dat de subsidieregeling werkgevers een beperking zou opleggen voor bedrijfseconomische ontslagen. ${ }^{27}$ Het doel van de NOW is immers om werkgelegenheidsverlies te voorkomen. De regering achtte het daarom onwenselijk dat werkgevers aanspraak maken op loonkostensubsidie en tegelijkertijd bedrijfseconomische ontslagen doorvoeren.

Het verbod op een bedrijfseconomisch ontslag geldt onder de NOW-1 in de periode van 18 maart 2020 tot en met 31 mei 2020 en onder de NOW-2 van 1 juni 2020 tot en met 30 september 2020. De NOW hanteert in dit verband een beperkt ontslagbegrip: het verbod ziet alleen op het indienen van een ontslagaanvraag bij het UWV op grond van artikel 7:669 lid 3 sub a BW. De werkgever wordt niet beperkt in de mogelijkheid om een beëindiging met wederzijds goedvinden na te streven en een vaststellingsovereenkomst te sluiten met een werknemer. De werkgever moet er wel op bedacht zijn dat dit zal leiden tot een daling van de loonsom. Deze daling heeft een effect op de hoogte van de subsidie.

\subsection{Gevolgen bij niet-naleving: de boete-opslag} Indien de werkgever deze verplichting niet nakomt en toch een ontslagaanvraag indient bij het UWV, dan neemt het UWV de aanvraag in behandeling en zal hij daarop beslissen. ${ }^{28}$ De aanvraag voor loonkostensubsidie is geen weigeringsgrond voor de verlening van de ontslagvergunning. ${ }^{29}$ De werkgever die de NOW heeft aangevraagd en tijdens de subsidieperiode toch een ontslagaanvraag indient bij het UWV, krijgt achteraf wel te maken met een lagere subsidievaststelling. Onder de NOW-1 geldt dat het loon van de werknemers voor wie de werkgever ontslag heeft aangevraagd, wordt verhoogd met $50 \%$. Dit volledige bedrag wordt vervolgens in mindering gebracht op de totale loonsom over de subsidieperiode. ${ }^{30}$ In $\S 3.2$ werd duidelijk dat dit een grote impact kan hebben op de hoogte van het subsidie-

26. Toelichting bij de NOW-1 (Stcrt. 2020, 19874, p. 15).

27. Brief over het Noodpakket banen en economie in verband met de uitbraak van het coronavirus (Kamerstukken / 2019/20, 35420, A).

28. Toelichting bij de NOW-1 (Stcrt. 2020, 19874, p. 15).

29. Het UWV zal proberen telefonisch contact te krijgen met de werkgever die een ontslagaanvraag heeft ingediend om hem te wijzen op de mogelijkheid de aanvraag alsnog in te trekken (Toelichting bij de NOW-1 (Stcrt. 2020, 19874, p. 16)).

30. Art. 7 lid 5 NOW-1. 
bedrag. Deze korting vindt plaats ongeacht of het UWV de ontslagvergunning heeft verleend en de werkgever de arbeidsovereenkomst daadwerkelijk heeft opgezegd. De $50 \%$ verhoging is dan ook snel omgedoopt tot een 'boete-opslag'. Dit is een bewuste keuze geweest van de regering: de NOW moest bij voorbaat duidelijkheid geven over de verplichtingen waaraan de werkgever die loonkostensubsidie ontvangt moet voldoen en wat de gevolgen zijn als de werkgever niet aan deze verplichting voldoet. ${ }^{31}$

Tijdens de looptijd van de NOW-1 zijn de ingrijpende overheidsmaatregelen tegen de verspreiding van het coronavirus steeds verder versoepeld. Het werd tegelijkertijd echter duidelijk dat de economische gevolgen van de coronacrisis langer zouden aanhouden dan aanvankelijk werd gedacht. De regering heeft bij de aankondiging van de NOW-2 erkend dat in het licht van deze omstandigheden ontslagen niet in alle gevallen te voorkomen zijn en dat er bedrijven zijn die verdergaande maatregelen moeten nemen. Om te voorkomen dat werkgevers vanwege het verbod op bedrijfseconomisch ontslag bij voorbaat geen beroep zouden doen op de NOW, heeft de regering besloten om de $50 \%$ boeteopslag niet terug te laten komen in de NOW-2. ${ }^{32}$ Deze versoepeling betekent niet dat het aanvragen van een bedrijfseconomisch ontslag onder de NOW-2 zonder gevolgen is. Onder de NOW-2 geldt dat er bij de vaststelling van de subsidie wordt gecorrigeerd voor het loon van de werknemers voor wie tijdens de subsidieperiode ontslag is angevraagd. Dit loon wordt voor $100 \%$ - in plaats van $150 \%$ - in mindering gebracht op de totale loonsom, ongeacht of het UWV de ontslagaanvraag heeft toegewezen. ${ }^{33}$ Hierbij geldt dat alleen wordt gecorrigeerd voor het loon over drie maanden in plaats van over de gehele subsidieperiode van vier maanden. ${ }^{34}$ Het is namelijk mogelijk dat een werknemer tijdens de subsidieperiode al uit dienst treedt. Door bij de correctie slechts het loon voor drie maanden mee te wegen, wordt voorkomen dat er een ongewenste dubbeling ontstaat bij de verlaging van de subsidie: enerzijds als gevolg van de loonsomdaling, anderzijds als gevolg van de correctie voor $100 \%{ }^{35}$

De subsidie wordt tot slot niet lager vastgesteld indien de werkgever een ontslagaanvraag heeft ingediend, maar deze binnen vijf werkdagen weer intrekt. ${ }^{36}$ Dit biedt de werkgever die tijdens de subsidieperiode abusievelijk een ontslagaanvraag indient de kans om dit te herstellen door de ontslagaanvraag in te trekken zonder dat dit gevolgen heeft voor het subsidiebedrag. In dit verband merk ik op dat de termijn van vijf dagen niet goed aansluit bij de praktijk rondom ontslagaanvragen. Regel- matig dient een werkgever eerst een voorlopige ontslagaanvraag in bij het UWV, waarvoor hij alleen enkele gegevens van de werknemer en zichzelf hoeft an te leveren (het A-formulier). ${ }^{37}$ De werkgever krijgt vervolgens veertien dagen van het UWV om de ontslagaanvraag verder aan te vullen. De werkgever heeft gedurende deze termijn de mogelijkheid om te onderzoeken of een beëindiging met wederzijds goedvinden mogelijk is, zonder het risico te lopen dat de werknemer zich strategisch ziekmeldt. Het was daarom logischer geweest om in de NOW aan te sluiten bij deze termijn van veertien dagen.

\subsection{Belangrijke afwegingen voor de werkgever}

Zowel onder de NOW-1 als onder de NOW-2 geldt dat de werkgever geen ontslagaanvraag wegens bedrijfseconomische redenen mag indienen bij het UWV in de periode dat hij loonkostensubsidie ontvangt onder de NOW. Aangezien de boete-opslag van 50\% onder de NOW-2 is afgeschaft, zijn de gevolgen van het niet naleven van deze verplichting in de tweede tranche minder verstrekkend. De NOW-2 sluit daarmee al meer aan op de huidige economische realiteit dan de NOW-1. Het doorvoeren van een bedrijfseconomisch ontslag kan onder beide tranches echter leiden tot een drastische verlaging van het subsidiebedrag. De werkgever kan zich wenden tot de middelen die ik onder $\S 3.3$ besprak om de effecten van de loonsomcorrectie te beperken. Naar verwachting zal de werkgever zich niet succesvol bij de rechter kunnen verzetten tegen de lagere subsidievaststelling wegens het doorvoeren van een bedrijfseconomisch ontslag: de kans dat de rechter zal oordelen dat de werkgever onevenredig wordt geraakt lijkt nihil indien een werkgever bewust ontslagen heeft doorgevoerd. Het uitgangspunt blijft immers dat de loonkostensubsidie bedoeld is om werkgelegenheid te behouden en ontslagen tegen te gaan. De NOW en bedrijfseconomisch ontslag gaan daarom eenvoudigweg niet goed samen. Een werkgever die in het huidige economische klimaat wordt gedwongen om te reorganiseren, zal daarmee moeten wachten tot na de subsidieperiode indien hij wil voorkomen dat de subsidie lager wordt vastgesteld en hij eventueel een deel van het voorschot moet terugbetalen. De werkgever kan tijdens de subsidieperiode al wel voorzichtig voorbereidingen treffen. Zo kan hij tijdens deze periode de ondernemingsraad om advies vragen over de voorgenomen reorganisatieplannen of gesprekken starten met de vakbonden over een sociaal plan. Op die manier zorgt de werkgever ervoor dat hij na afloop van de subsidieperiode eerder over kan gaan tot de uitvoering van de reorganisatie en minder tijd verliest.

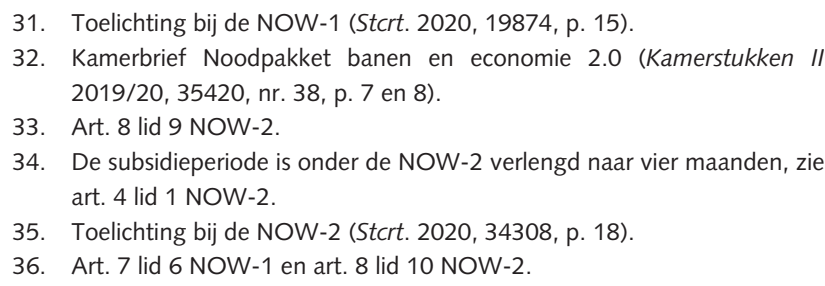

37. Zie de website van het UWV voor het A-formulier en de mogelijkheid tot uitstel: www.uwv.nl/werkgevers/formulieren/aanvragen-ontslag vergunning-wegens-bedrijfseconomische-redenen-deel-a.aspx. 


\section{Collectief ontslag onder de NOW-2}

\subsection{Wet melding collectief ontslag en de NOW}

Het verbod op bedrijfseconomisch ontslag is, zoals gezegd, onder de NOW-2 enigszins versoepeld door de afschaffing van de boete-opslag. De regering heeft benadrukt dat het ontslag een ultimum remedium blijft waar de werkgever pas op terug moet vallen indien andere maatregelen niet het gewenste effect hebben. ${ }^{38}$ Als compromis voor de afschaffing van de boete-opslag zijn in de NOW-2 aanvullende verplichtingen opgenomen die zien op het doorvoeren van een collectief ontslag. Om het belang van goed overleg met de vakbonden te onderstrepen en om misbruik bij bedrijfseconomisch ontslag tegen te gaan, is onder de NOW-2 een expliciete rol weggelegd voor de vakbonden op het moment dat een werkgever tijdens de subsidieperiode wil overgaan tot een collectief ontslag in de zin de Wet melding collectief ontslag ('WMCO'). ${ }^{39}$ De werkgever die in de periode van 30 mei 2020 tot en met 30 september 2020 een melding doet op grond van de WMCO, is volgens artikel 15 sub c NOW-2 verplicht om:

a. over het voorgenomen collectief ontslag overleg te voeren met de vakbonden of met een andere vertegenwoordiging van werknemers, welk overleg gericht moet zijn op het bereiken van een overeenstemming over het aantal te vervallen arbeidsplaatsen; en

b. niet eerder dan vier weken na het doen van de WMCO-melding ontslagaanvragen in te dienen bij het UWV op grond van artikel 7:669 lid 3 sub a BW in het kader van het collectief ontslag.

De werkgever moet bij de aanvraag verklaren dat hij zich aan deze verplichtingen zal houden en gedurende een periode van vier weken zal overleggen met de vakbonden over de voorgenomen ontslagen. Dit sluit aan bij de verplichting uit de WMCO om de belanghebbende vakbonden te raadplegen en het daarmee samenhangende verbod om gedurende een maand na de melding geen beëindigingshandelingen te verrichten. ${ }^{40}$ De NOW-2 hanteert echter een ander, beperkter ontslagbegrip dan de WMCO. De NOW-2 ziet alleen op de opzegging via het UWV, terwijl voor de WMCO ook andere vormen van beëindiging relevant zijn. Onder de WMCO telt een beëindiging met wederzijds goedvinden of een ontbinding door de kantonrechter om bedrijfseconomische redenen ook mee bij de vaststelling of de drempel van twintig of meer werknemers wordt gehaald. Alleen een beëindiging uitsluitend om redenen die de persoon van de werknemer betreffen of een beëindiging tijdens proeftijd telt niet mee. ${ }^{41}$

38. Toelichting bij de NOW-2 (Stcrt. 2020, 34308, p. 18).

39. Zie de Toelichting bij de NOW-2 (Stcrt. 2020, 34308, p. 18)

40. Art. 3 en art. 5 a WMCO.

41. Art. 2 en art. 3 WMCO.
5.2 Gevolgen van niet naleven en de rol van de vakbonden

Voldoet de werkgever niet aan bovenstaande verplichting en doet hij tijdens de subsidieperiode een melding op grond van de WMCO én dient hij tijdens de subsidieperiode voor twintig of meer werknemers binnen hetzelfde UWV-werkgebied een ontslagaanvraag in, dan wordt het totale subsidiebedrag waar de werkgever recht op heeft met 5\% gekort (art. 9 lid 1 NOW-2). Ook hier hanteert de NOW-2 een beperkter ontslagbegrip dan de WMCO en tellen alleen ontslagaanvragen via het UWV mee. De NOW verbindt hier dus een consequentie aan het niet naleven van de WMCO. De vraag is in hoeverre dit wenselijk is, omdat de WMCO zelf al voorziet in sancties op het negeren van de WMCOvoorschriften. ${ }^{42}$ Bovendien zal het UWV een ontslagaanvraag niet in behandeling nemen indien de werkgever de vakbonden niet heeft geraadpleegd. ${ }^{43}$ Dit biedt al voldoende stok achter de deur om te melden en met de vakbonden in overleg te treden. Het is onduidelijk waarom de NOW ook nog een sanctie zou moeten bevatten om dit overleg te bevorderen.

De korting van $5 \%$ op het totale subsidiebedrag vindt in ieder geval niet plaats indien de werkgever met de belanghebbende vakbonden of een andere vertegenwoordiging van werkgevers overeenstemming heeft bereikt over de noodzaak van het aantal te vervallen arbeidsplaatsen (art. 9 lid 2 sub a NOW-2). Een verklaring van de betrokken vakbonden, zoals bedoeld in artikel 2 Ontslagregeling, dat voor een doelmatige bedrijfsvoering het door de werkgever voorgestelde aantal te vervallen arbeidsplaatsen noodzakelijk is, is niet voldoende. ${ }^{44}$ Lukt het de werkgever niet om een akkoord te bereiken, dan kan hij alsnog de korting voorkomen door gezamenlijk met de vakbonden een daarvoor ingerichte commissie van de Stichting van de Arbeid ('STAR') te verzoeken om de noodzakelijkheid van het voorgestelde aantal te vervallen arbeidsplaatsen te beoordelen (art. 9 lid 2 sub b NOW-2). De STAR heeft voor dit doel de Commissie voor geschilbeslechting ingericht. Deze commissie bestaat uit een onafhankelijke voorzitter, twee leden namens werkgeversorganisaties en twee leden namens de vakbonden. De behandeling van een gezamenlijk verzoek zal ongeveer vijf werkdagen duren. ${ }^{45}$ De werkgever zal bij de subsidievaststelling desgevraagd moeten kunnen aantonen dat hij een akkoord heeft bereikt of dat hij een gezamenlijk verzoek heeft ingediend bij de STAR. ${ }^{46}$

\subsection{Belangrijke afwegingen voor de werkgever} De NOW-2 legt de werkgever die loonkostensubsidie ontvangt aanvullende verplichtingen op die de mogelijkheid beperken om tijdens de subsidieperiode een

42. Zie art. 7 WMCO

43. Art. 6 lid 1 WMCO

44. Toelichting bij de NOW-2 (Stcrt. 2020, 34308, p. 19).

45. Zie de website van de STAR: www.stvda.nl/-/media/stvda/downloads/ publicaties/2020/commissie-voor-geschilbeslechting.pdf? $\mathrm{la}=\mathrm{nl} \&$ hash=A8CF4A4CAF6CCD4F067F8E074E6C2D40

46. Toelichting bij de NOW-2 (Stcrt. 2020, 34308, p. 18). 
collectief ontslag door te voeren. Naast het feit dat het indienen van een ontslagaanvraag bij het UWV tijdens de subsidieperiode leidt tot een lagere vaststelling van de subsidie, verplicht de NOW-2 de werkgever om een akkoord te bereiken met de vakbonden op het moment dat hij een melding op grond van de WMCO doet. De werkgever kan hieraan ontkomen door indien mogelijk de bedrijfseconomische ontslagen tactisch te spreiden over verschillende UWV-werkgebieden, zodat niet binnen één werkgebied de drempel van twintig of meer werknemers wordt behaald. Schending van deze verplichting heeft verder slechts beperkte gevolgen. Houdt de werkgever zich niet aan deze verplichting én dient hij tijdens de subsidieperiode twintig of meer ontslagaanvragen in binnen hetzelfde UWV-werkgebied, dan wordt het totale subsidiebedrag namelijk slechts met 5\% gekort. De NOW-2 bevat daarnaast twee escape-routes om deze korting te ontlopen. Ik vraag me echter af of werkgevers zich zullen inspannen een akkoord te bereiken of een gezamenlijk verzoek bij de STAR in te dienen om een 5\% korting te voorkomen. Het staat werkgevers die een beroep doen op NOW-2 bovendien vrij om tijdens de subsidieperiode voorbereidingen te treffen voor een collectief ontslag en alvast de WMCO-melding te doen. De werkgever kan op die manier de subsidieperiode gebruiken om de belanghebbende vakbonden te raadplegen. $\mathrm{Na}$ afloop van de subsidieperiode zal de standstill-periode van een maand waarschijnlijk zijn verstreken en kan de werkgever overgaan tot de implementatie van het beoogde collectief ontslag.

\section{Afsluiting}

De regering heeft binnen korte tijd een omvangrijk pakket aan steunmaatregelen van de grond gekregen om bedrijven te ondersteunen die als gevolg van de coronacrisis in zwaar weer verkeren. De NOW is geintroduceerd met als belangrijkste doel om werkgevers snel tegemoet te komen in de betaling van de loonkosten. Het doel van de NOW was eenvoudig en duidelijk: werkgevers moesten in staat worden gesteld hun werknemers tijdens de periode van economische krimp zo veel mogelijk in dienst te houden. De NOW was daarmee gericht op het voorkomen van ontslagen en het zo veel mogelijk behouden van de werkgelegenheid. Dit heeft als gevolg dat de werkgever die is aangewezen op loonkostensubsidie om het hoofd tijdens de coronacrisis boven water te kunnen houden, in vergaande mate beperkt wordt in zijn mogelijkheid om een ontslagbeleid te voeren. De werkgever moet bij het aanvragen van loonkostensubsidie onder de NOW anticiperen op de ontslagverplichtingen en inschatten of hij ondanks de subsidie ook zal moeten besparen op de loonkosten. Aangezien een loonsomdaling en bedrijfseconomisch ontslag vergaande consequenties hebben voor de hoogte van de loonkostensubsidie en daardoor kunnen leiden tot een terugvordering van het voorschot, zal de werkgever op dit punt van tevoren een weloverwogen beslis- sing moeten nemen. Dit knelt in de huidige economische omstandigheden die werkgevers dwingen om structurele maatregelen te nemen om hun onderneming in leven te houden. De NOW-2 geeft al meer blijk van de economische realiteit, aangezien de boete-opslag bij een bedrijfseconomisch ontslag is afgeschaft. Dit neemt niet weg dat ook onder de NOW-2 het uitgangspunt is dat de werkgever niet mag overgaan tot een bedrijfseconomisch ontslag en dat dit zal leiden tot een lagere vaststelling van de subsidie indien hij toch daarvoor kiest.

Het subsidiëren van de loonkosten zal niet in alle gevallen kunnen voorkomen dat bedrijven omvallen, indien er tegelijkertijd geen ruimte bestaat om te herstructureren. Het Centraal Planbureau ('CPB') concludeert in de recente publicatie 'Lessen voor de NOW' dat de NOW een geschikte maatregel is om werkloosheid op korte termijn tegen te gaan, maar dat op de lange termijn aanvullende maatregelen nodig zijn en meer zal moeten worden ingezet op reallocatie. ${ }^{47}$ De regering lijkt dit ook in te zien en heeft bij de aankondiging van de NOW-3 overwogen dat bedrijven bij langdurig omzetverlies hun bedrijfsvoering moeten kunnen aanpassen. ${ }^{48}$ De NOW-3 zal daarom meer ruimte bieden voor werkgevers om vanaf oktober 2020 hun loonsom te laten dalen zonder dat dit zal leiden tot een lagere vaststelling van de loonkostensubsidie. Het percentage waarmee de werkgever zijn loonsom omlaag mag brengen loopt op van $10 \%$ in de derde tranche $(1$ oktober - 31 december 2020), naar $15 \%$ in de vierde tranche (1 januari - 31 maart 2021) en 20\% in de vijfde tranche (1 april 2021 - 30 juni 2021). Daarnaast wordt de $5 \%$ korting bij bedrijfseconomisch ontslag losgelaten en wordt niet meer 100\% (in de NOW-2, 150\% in de NOW-1) van het loon van de werknemers voor wie bedrijfseconomisch ontslag is aangevraagd in mindering gebracht op de subsidie. Hier staat tegenover dat het maximaal te vergoeden percentage van de loonsom zal dalen van $90 \%$ naar $80 \%$ in de derde tranche, naar $70 \%$ in de vierde tranche en naar $60 \%$ in de vijfde tranche. Al met al ziet het ernaar uit dat de NOW-3 voor een belangrijk deel een versoepeling zal meebrengen van de kernverplichtingen die zien op bedrijfseconomisch ontslag. Dit biedt bedrijven meer ruimte om voorlopig een beroep te blijven doen op overheidssteun, maar tegelijkertijd de blik op de toekomst te richten en na te denken over meer structurele herstructureringsmaatregelen. Dit lijkt in het licht van de aanhoudende coronacrisis en de voorspelde economische recessie een goede ontwikkeling. Aan de andere kant betekent dit dat de werkgever met nog meer verschillende factoren rekening zal moeten houden dan onder de NOW-1 en de NOW-2. De werkgever zal moeten balanceren tussen enerzijds de ruimte die de NOW-3 bijvoorbeeld biedt

47. Zie de website van het CPB: www.cpb.nl/lessen-voor-de-now.

48. Zie de Kamerbrief Steun- en herstelpakket (Kamerstukken I 2019/20, 35420, nr. 105, p. 5) en de Kamerbrief Tijdelijke Noodmaatregel Overbrugging voor Werkbehoud 3, vaststellingsproces NOW 1 en wijzigingsregeling NOW 1 en 2 van 30 september 2020 (Kamerstukken II 2019/20, 35420, nr. 142, p. 2). 
om de loonsom met een bepaald percentage te laten dalen en anderzijds de beperkingen die ook onder de NOW-3 zullen blijven bestaan wanneer het gaat om bedrijfseconomisch ontslag. Zo zal de NOW-3 een nieuwe inspanningsverplichting bevatten voor de werkgever om werknemers die afvloeien naar nieuw werk te begeleiden, waarbij een korting van 5\% wordt toegepast indien de werkgever daarover geen contact heeft gezocht met het UWV terwijl hij bedrijfseconomisch ontslag aanvraagt. $^{49}$ 